\title{
Pengembangan Model Senam Si Buyung Untuk Peningkatan Kemampuan Motorik Kasar Anak
}

\author{
Siti Maryuqoh ${ }^{1 凶}$, Panggung Sutapa $^{1}$ \\ Pendidikan Anak Usia Dini, Universitas Negri Yogyakarta, Indonesia(1) \\ DOI: $10.31004 /$ obsesi.v6i3.2126
}

\begin{abstract}
Abstrak
Tujuan penelitian adalah mengembangkan dan menganalisis efektivitas materi senam Si Buyung yang sesuai dengan karakteristik anak TK kelompok B. Jenis penelitian ini adalah Research and Developtment (R\&D). Subjek penelitian adalah anak TK kelompok B di wilayah Kecamatan Trucuk Kabupaten Klaten Provinsi Jawa Tengah, dengan rentang usia anak 5-6 tahun. Teknik pengumpulan data yang digunakaan adalah: wawancara mendalam (indepth interview), dokumentasi, dan tes. Teknik analisis data yang digunakan adalah analisis kualitatif, dan statistik deskriptif. Hasil penelitian adalah materi senam Si Buyung yang sesuai dengan karakteristik anak TK kelompok B adalah senam si Buyung dengan menirukan gerakan binatang seperti menirukan gerakan binatang kucing berlari, monyet melempar bola, ayam berjalan di atas balok, ular berlari, dan katak melompat. Model senam Si Buyung secara efektif dapat meningkatkan kemampuan motorik kasar anak TK kelompok B. Hasil pengembangan model senam Si Buyung ini dapat digunakan oleh guru TK untuk meningkatkan motivasi dan hasil belajar anak dalam pembelajaran motorik kasar.
\end{abstract}

\section{Kata kunci: senam si buyung; kemampuan motorik kasar; anak usia dini}

\begin{abstract}
The purpose of the study was to develop and analyze the effectiveness of Si Buyung's gymnastic materials according to the characteristics of group B kindergarten children. This type of research is Research and Development (R\&D). The research subjects were kindergarten children in group B in the Trucuk District, Klaten Regency, Central Java Province, with an age range of 5-6 years.The data collection techniques used are: in-depth interviews, documentation, and tests. The data analysis technique used is qualitative analysis and descriptive statistics. The result of this research is that Si Buyung's gymnastic material that is in accordance with the characteristics of Kindergarten children in group B is Si Buyung's gymnastics by imitating animal movements such as imitating the movement of animals running cats, monkeys throwing balls, chickens walking on blocks, snakes running, and frogs jumping. Si Buyung's gymnastic model can effectively improve the gross motor skills of group B kindergarten children.The results of developing the Si Buyung exercise model can be used by kindergarten teachers to increase children's motivation and learning outcomes in gross motor learning.
\end{abstract}

Keywords: si buyung's gymnastics; gross motor ability; early childhood

Copyright (c) 2022 Siti Maryuqoh, Panggung Sutapa

$\triangle$ Corresponding author :

Email Address : smaryuqoh@gmail.com (alamat koresponden)

Received 22 November 2021, Accepted 9 January 2022, Published 16 January 2022 


\section{PENDAHULUAN}

Pendidikan anak usia dini merupakan pendidikan yang paling mendasar dan menempati kedudukan sebagai golden age, agar anak memiliki kesiapan dalam memasuki pendidikan lebih lanjut (Rakimahwati et al., 2018). Menurut Mutiah, anak usia dini merupakan individu yang unik dan memiliki karakteristik tersendiri sesuai sesuai dengan tahapan usianya (Rakimahwati et al., 2018). Musfiroh menjelaskan aspek yang dikembangkan dalam pendidikan anak usia dini adalah aspek pengembangan pembiasaan meliputi sosial, emosi, kemandirian, moral, dan nilai-nilai agama, serta pengembangan kemampuan dasar yang meliputi pengembangan bahasa, kognitif, dan fisik motorik (Kuraedah \& Anhusadar, 2020). Aspek perkembangan anak dapat berkembang dengan baik apabila mendapat stimulas yang baik (Baan et al., 2020).

Salah satu pendidikan anak usia dini adalah TK, yaitu pendidikan untuk membantu pertumbuhan dan perkembangan jasmani dan rohani anak di luar lingkungan keluarga sebelum memasuki pendidikan dasar (Darmiatun \& Mayar, 2020). Tujuan pendidikan TK membantu meletakkan dasar untuk mengembangan sikap, perilaku, pengetahuan, keterampilan dan kreativitas untuk pertumbuhan dan perkembangan anak (Wandi \& Mayar, 2020).

Aspek perkembangan yang penting peranannya dalam kehidupan anak adalah aspek fisik motorik (Fitri \& Imansari, 2021). Hurlock mencatat beberapa alasan tentang fungsi perkembangan motorik bagi konstelasi perkembangan individu, yaitu: melalui keterampilan motorik anak dapat menghibur dirinya dan memperoleh perasaan senang. Melalui keterampilan, motorik anak dapat beranjak dari kondisi "helplessness" (tidak berdaya) pada bulan-bulan pertama kehidupannya, menuju kondisi yang independence" (bebas, tidak bergantung) (Saripudin, 2019)

Motorik anak dibedakan menjadi dua yaitu, motorik kasar dan motorik halus. Motorik kasar ialah kegiatan yang melibatkan otot-otot besar dengan aktivitas menggunakan anggota seluruh tubuh, contoh berlari, melompat (Claudia et al., 2018). Mosby's Medical Dictionary menambahkan keterampilan motorik kasar termasuk gerakan tubuh umum seperti melompat, melompat, berlari, menyeimbangkan, kekuatan dan koordinasi (Tanto \& Sufyana, 2020). Erlinda dkk menjelaskan keterampilan motorik kasar memerlukan beberapa unsur, diantaranya: kecepatan, kekuatan, ketahanan, kelincahan, fleksibilitas, koordinasi, dan keseimbangan (Fitri \& Imansari, 2021). Keterampilan motorik menggambarkan berbagai kompetensi fisik, termasuk keseimbangan dan stabilitas, gerakan terkoordinasi, dan manipulasi objek (Nasution \& Sutapa, 2021).

Perkembangan motorik kasar berbeda antara anak yang satu dengan yang lainnya, karena dipengaruhi faktor internal dan faktor eksternal. Faktor internal terdiri dari minat anak, gen, sedangkan faktor eksternal yaitu lingkungan belajar, pendidikan orang tua, dan lokasi anak tinggal (Laely, 2020). Berdasarkan pengamatan di TK, kemampuan motorik kasar anak TK pada umumnya belum berkembangan secara maksimal, karena kreativitas guru TK dalam pembelajaran motorik di TK masih kurang, guru kurang mampu mengembangkan metode atau media pembelajaran motorik. Selain itu, sarana dan prasarana serta alat peraga pembelajaran motorik di TK umumnya masih terbatas.

Decaprio menjelaskan motorik kasar merupakan suatu keahlian yang memerlukan koordinasi sebagian besar bagian tubuh anak (Septiana \& Widiastuti, 2020). Motorik kasar merupakan suatu aktivitas fisik yang menggunakan seluruh otot-otot besar pada tubuh atau menggunakan sebagian besar otot yang ada dalam tubuh (Septiana \& Widiastuti, 2020). Motorik kasar berhubungan dengan perkembangan dan penyelarasan otot kasar seperti melempar, melompat, berlari dan berjalan (Meriyati et al., 2021). Anak yang memiliki kemampuan gerakan dasar lokomotor yang baik akan dapat membantu dirinya menampilkan sikap yang baik dan terampil menyelesaikan persoalan anak dalam kehidupan sehari-hari (Widiarti et al., 2021). 
Grant JP menjelaskan perkembangan motorik kasar berkaitan dengan unsur kematangan, pengendalian gerak tubuh dan erat kaitannyadengan perkembangan pusat motorik di otak yakni korteks frontalis yaitu area 4 Broadmann yang merupakan area motorik primer (Marischa, 2017). Gallahue menjelaskan bahwa untuk mengembangkan pola gerak anak sebaiknya dilakukan melalui aktivitas menari, permainan, olahraga, dan senam (Prahesti \& Dewi, 2020). Kemampuan motorik kasar yang baik akan memberikan dampak positif terhadap tingkat kesehatan anak, karena anak akan gemar berolahraga dan melakukan gerakan-gerakan yang dapat memperbaiki sirkulasi darah, pernafasan, dan pembentukan postur tubuh yang ideal (Hayati, 2020).

Ailwood menjelaskan perkembangan kemampuan motorik pada anak membutuhkan aktivitas fisik untuk pertumbuhan dan perkembangannya (Ramdani \& Azizah, 2020). Cara untuk mengoptimalkan perkembangan motorik kasar anak usia dini, yaitu melalui aktivitas bermain seperti bermain bola, menari, bermain perang-perangan, berolahraga, termasuk senam. Senam merupakan salah satu olahraga yang dapat dijadikan sebagai salah satu alternatif untuk mengembangkan motorik kasar pada anak usia dini. Berbagai macam senam diantaranya senam si buyung, senam irama dan senam fantasi. Senam adalah suatu latihan tubuh yang dipilih dan dikonstruksi dan sengaja dilakukan secara sistematis dengan tujuan meningkatkan kesegaran jasmani, mengembangan keterampilan dan menanamkan nilai-nilai mental spiritual (Baan et al., 2020).

Berdasarkan pendapat ini, maka ada beberapa faktor yang dapat memengaruhi kemampuan motorik kasar anak, diantaranya adalah latihan senam si buyung. Hasil penelitian Eriani dan Dimyati menyimpulkan bahwa senam si buyung dirancang agar dapat memberikan kebebasan bergerak sesuai dengan imajinasi, sehingga mendorong anak-anak untuk mengalami, menemukan, dan belajar dengan caranya sendiri. Selain itu anak-anak dapat mengekespresikan diri dengan menggerakan tubuh untuk mengekspresikan ide, pikiran, dan emosi (Eriani \& Dimyati, 2020).

Hasil penelitian Pahendra et al. (2021) menyimpulkan permainan bola keranjang berhasil meningkatkan kemampuan motorik kasar anak usia dini. Hasil penelitian Hartina \& Abubakar (2019) menyimpulkan video senam ceria sangat layak dan sangat efektif sebagai media pembelajaran untuk meningkatkan ketrampilan motorik kasar siswa down syndrome. Penelitian Wijayanti et al. (2020) menyimpulkan keterampilan motorik kasar anak dapat ditingkatkan melalui kegiatan senam irama. Penelitian (Sukma \& Wafi, 2018) menyimpulkan kegiatan senam irama dalam meningkatkan kemampuan motorik kasar anak. Penelitian Ulfah \& Putra (2021) menyimpulkan penerapan senam irama dalam meningkatkan kemampuan motorik kasar anak usia dini. Semakin banyak kegiatan yang bervariatif dan inovatif maka peluang untuk meningkatkan kemampuan motorik kasar pada anak sehingga dapat berkembang dengan optimal. Hasil penelitian (Annisa \& Sutapa, 2019) menyimpulkan bahwa pembelajaran berbasis alam efektif meningkatkan keterampilan motorik karena dengan menggunakan panca inderanya, anak memiliki pengalaman belajar melalui bermain, sesuai dengan kebutuhan usia, menggunakan benda konkrit, hingga kegiatan yang menantang. Robinson et al. menambhakan bahwa anak-anak yang terlibat dalam aktivitas fisik, mereka akan memiliki kompetensi dasar dalam keterampilan motorik dasar, dan anakanak belajar keterampilan dasar motorik melalui program gerakan yang dirancang dengan baik dan terencana (Nasution \& Sutapa, 2021)

Gerakan senam Si Buyung yang diberikan oleh guru TK pada umumnya menggunakan gerakan sesuai keinginan guru dan diberikan tanpa menggunakan iringan lagu (musik), serta belum banyak dikembangkan senam Si Buyung yang memadukan gerakan binatang dan iringan lagu-lagu anak. Penggunaan audio visual dalam pembelajaran senam perlu digunakan oleh guru sebagai salah satu media pembelajaran yang cukup efektif untuk meningkatkan kemampuan motorik kasar anak, karena anak TK dapat menirukan gerakan yang ditunjukkan dalam audio visual. Di samping itu, audio visual dapat mendorong motivasi belajar anak. Oleh karena itu, diperlukan pengembangan model senam Si Buyung 
berdasarkan gerakan binatang dan diiringi lagu anak-anak dalam bentuk buku dan video, sehingga dapat digunakan dengan mudah oleh guru TK untuk memberikan latihan pengembangan motorik kasar anak.

\section{METODOLOGI}

Jenis penelitian ini adalah Research and Developtment (R\&D) yaitu metode penelitian yang digunakan untuk menghasilkan produk, dan menguji keefektifan produk. Pada penelitian ini produk yang dimaksud adalah model pengembangan senam Si Buyung untuk meningkatkan kemampuan motorik kasar anak usia dini. Model pengembangan yang digunakan mengacu model Borg dan Gall sebagaimana pada gambar 1.

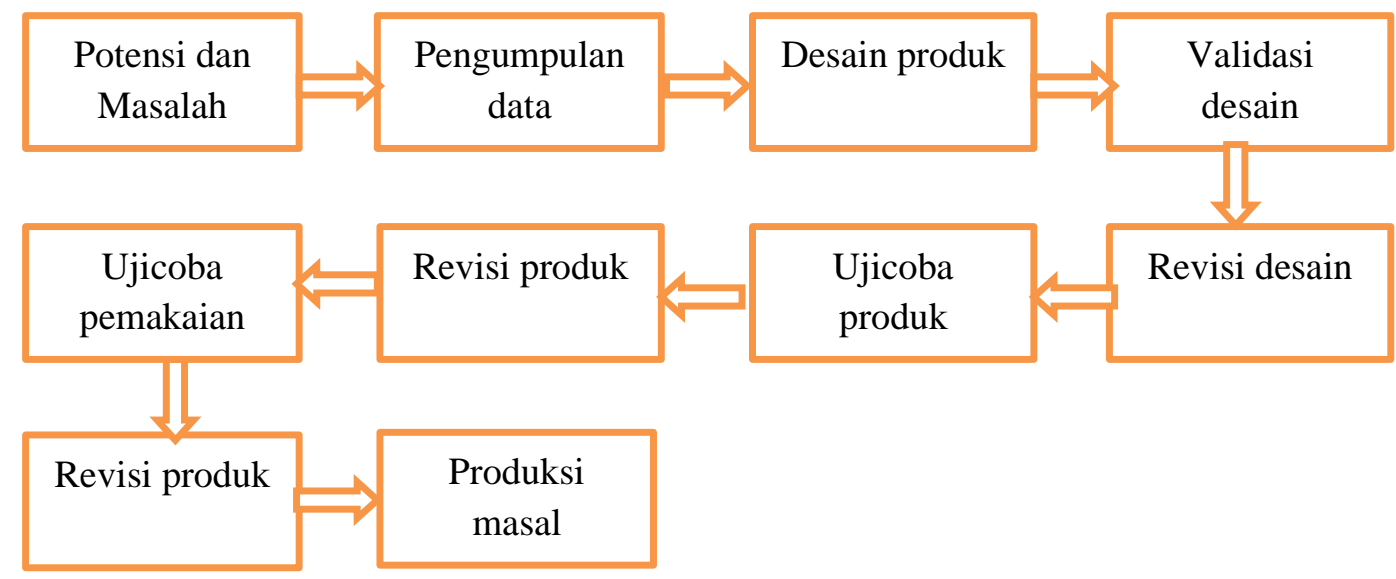

Gambar 1. Langkah-langkah Research and Development (RED) (Sugiyono, 2013)

Teknik pengumpulan data menggunakan wawancara mendalam, dokumentasi, dan tes. Tes digunakan untuk mengukur kemampuan motorik kasar anak. Materi tes dikembangkan berdasarkan indikator dari Sujiono \& Sujiono yang meliputi: kecepatan, kekuatan, koordinasi, keseimbangan, dan kelincahan (Sujiono \& Sujiono, 2010).

Teknik analisis data yang digunakan adalah analisis kualitatif untuk menganalisis data yang berupa narasi, dan gambar, sedangkan untuk menganalisis data dalam bentuk angka digunakan statistik deskriptif. Analisis kualitatif dilakukan dengan model interaktif dari Miles dan Huberman yang meliputi reduksi data, sajian data, dan penarikan kesimpulan (Sugiyono, 2013). Analisis deskriptif untuk mengolah kategori nilai kemampuan motorik kasar yang diperoleh anak dalam melakukan senam Si Buyung dengan patokan skala lima yaitu: bak sekali, baik, cukup, kurang, sangat kurang (Arikunto, 2015). Hasil pengembangan model senam Si Buyung ini berupa buku dan video. Model pengembangan senam Si Buyung dikatakan efektif apabila ada perbedaan signifikan antara skor kemampuan motorik kasar sebelum dan sesudah diberikan latihan senam Si Buyung.

\section{HASIL DAN PEMBAHASAN}

Setelah melalui tahapan pengembangan dengan arahan dosen Pembimbing dan dosen Validator, akhirnya tahapan ujicoba produk model senam Si Buyung telah dibuat, selama 10 menit dengan materi inti senam Si Buyung yaitu menirukan gerakan: (1) kucing berlari dengan iringan lagu "Naik ke Puncak Gunung" (1 menit), (2) monyet melempar bola dengan iringan lagu "Pesawat jet", dan "Kupu-kupu yang Lucu" (2 menit), (3) ayam berjalan di atas balok dengan diiringi lagu "Naik Delman" (1 menit), (4) ular berlari dengan iringan lagu "Kring-Kring Ada Sepeda" (1 menit), dan (5) katak melompat dengan iringan lagu "Kodok Ngorek" (1 menit). Sebelum gerakan inti, didahului dengan gerakan pemanasan (2 menit) dengan iringan lagu "Lingkaran kecil" dan "Naik Kereta Api", serta diakhiri gerakan 
pendinginan (2 menit) dengan iringan lagu "Kasih Ibu" dan "Desa yang Kucinta". Untuk menilai kemampuan motorik anak usia dini digunakan indikator, yaitu kecepatan, kekuatan, koordinasi, keseimbangan, dan kelincahan.

\section{Desain Ujicoba Produk}

Sebelum produk benar-benar dilakukuan uji coba pada subjek, produk pengembangan yang berupa buku panduan dan video tutorial dilakukan validasi. Validator desain produk terdiri atas: (1) Prof. Dr. Endang Rini Sukamti, M.S; (2) Dr. Sujarwo, M.Pd; (3) Dra. Sri Mawarti, M.Pd. Berdasarkan penilaian ketiga validator terhadap materi dan media yang digunakan untuk mengembangkan senam Si Buyung dinyatakan layak.

\section{Uji Coba Produk Terbatas}

Setelah dilakukannya uji coba terbatas pada 15 guru, kemudian dilakukan revisi produk yang terkait tentang kekurangan yang ditemukan pada uji coba terbatas. Berdasarkan pendapat guru, senam model Si Buyung mudah ditirukan. Hanya ada sedikit masukan dari beberapa guru untuk perbaikan model senam Si Buyung, terkait dengan posisi kaki dan tangan yang perlu diperjelas kembali.

\section{Uji Coba Lapangan Utama}

Hasil produk yang telah direvisi kemudian diujikan pada uji lapangan utama kepada 12 anak. Berdasarkan hasil uji coba diketahui bahwa model senam Si Buyung dapat dengan mudah ditirukan oleh anak-anak. Berdasarkan pengamatan dan diskusi dengan guru, ada beberapa gerakan yang perlu dipertegas kembali. Selanjutnya produk dilakukan revisi kembali sebelum digunakan pada tahap lapangan operasional.

\section{Uji Coba Operasional}

Uji lapangan operasional menggunakan pendekatan time series. Pendekatan ini digunakan karena ingin melihat keefektifan model yang dikembangkan dengan menguji cobakan selama 5 kali pengulangan pada sejumlah 12 dan 15 anak. Berdasarkan pengamatan, gerakan anak untuk menirukan senan Si Buyung dari 5 kali pengulangan relatif sama, dan anak semakin trampil menirukan gerakan senam Si Buyung, dan ceria melakukan senam Si Buyung karena gerakan tersebut diiringi dengan lagu-lagu yang sudah tidak asing lagi di telinga anak-anak.

\section{Uji Coba Produk pada Subjek Penelitian}

Setelah desain produk dilakukan ujicoba, dan telah dilakukan perbaikan, akhirnya produk dapat dilakukan ujicoba lapangan atau di sekolah-sekolah. Subjek uji coba dalam penelitian ini adalah anak TK kelompok B di wilayah Kecamatan Trucuk Kabupaten Klaten Provinsi Jawa Tengah, dengan rentang usia anak 5-6 tahun.

\section{Uji Coba Lapangan Terbatas}

Uji coba lapangan terbatas melibatkan guru dan anak kelas B sebanyak 15 anak TK ABA Bero IV Trucuk Klaten. Sebelum diberikan senam Si Buyung, dilakukan prestest untuk mengetahui kemampuan motorik kasar anak, dengan hasil seperti tabel 1.

Pada tabel 1 diketahui dari 15 anak, ada 5 anak (33\%) memperoleh nilai dengan kategori baik sekali, dan ada 7 anak (47\%) memperoleh nilai dengan kategori baik, Dari temuan ini diketahui bahwa sebagian besar anak memiliki kemampuan motorik kasar dengan kategori baik sebelum diberikan senam Si Buyung. Indikator yang digunakan untuk menilai kemampuan motorik kasar anak meliputi: kecepatan, kekuatan, koordinasi, keseimbangan, dan kelincahan (Sujiono \& Sujiono, 2010). Sesudah diberikan senam Si Buyung selama 5 kali (hari) @ 30, kemampuan motorik kasar anak semakin meningkat sebagaimana dapat dilihat pada tabel 2. 
Tabel 1 Kemampuan Motorik Kasar Anak Sebelum Diberikan Senam Si Buyung

\begin{tabular}{clcc}
\hline Nilai & Kategori & Jumlah Anak & Persentase \\
\hline $80-100$ & Baik sekali & 5 & $33 \%$ \\
$66-79$ & Baik & 7 & $47 \%$ \\
$56-65$ & Cukup & 0 & $0 \%$ \\
$40-55$ & Kurang & 3 & $20 \%$ \\
$0-39$ & Sangat kurang & 0 & $0 \%$ \\
\hline \multicolumn{2}{c}{ Jumlah } & 15 & $100 \%$ \\
\hline
\end{tabular}

Tabel 2 Kemampuan Motorik Kasar Anak Sesudah Diberikan Senam Si Buyung

\begin{tabular}{clcc}
\hline Nilai & \multicolumn{1}{c}{ Kategori } & Jumlah Anak & Persentase \\
\hline $80-100$ & Baik sekali & 6 & $40 \%$ \\
$66-79$ & Baik & 8 & $53 \%$ \\
$56-65$ & Cukup & 1 & $7 \%$ \\
$40-55$ & Kurang & 0 & $0 \%$ \\
$0-39$ & Sangat kurang & 0 & $0 \%$ \\
\hline & Jumlah & 15 & $100 \%$ \\
\hline
\end{tabular}

Pada tabel 2 diketahui bahwa dari 15 anak, ada 6 anak (40\%) memperoleh nilai dengan kategori baik sekali, dan ada 8 anak (53\%) memperoleh nilai dengan kategori baik. Dari temuan ini diketahui bahwa sebagian besar anak memiliki kemampuan motorik kasar dengan kategori baik sesudah diberikan senam Si Buyung. Peningkatan kemampuan motorik kasar anak sebelum dan sesudah diberikan senam Si Buyung, dapat disajikan pada tabel 3. .

Tabel 3 Perbandingan Kemampuan Motorik Kasar Anak Sebelum dan Sesudah Diberikan Si Buyung (Pretest-Posttest)

\begin{tabular}{clcccc}
\hline \multirow{2}{*}{ Nilai } & \multirow{2}{*}{ Kategori } & \multicolumn{2}{c}{ Nilai Pretest } & \multicolumn{2}{c}{ Nilai Posttest } \\
\cline { 3 - 6 } & & Jumlah & Persentase & Jumlah & Persentase \\
\hline $80-100$ & Baik sekali & 5 & $33 \%$ & 6 & $40 \%$ \\
$66-79$ & Baik & 7 & $47 \%$ & 8 & $53 \%$ \\
$56-65$ & Cukup & 0 & $0 \%$ & 1 & $7 \%$ \\
$40-55$ & Kurang & 3 & $20 \%$ & 0 & $0 \%$ \\
$0-39$ & Sangat kurang & 0 & $0 \%$ & 0 & $0 \%$ \\
\hline \multicolumn{2}{c}{ Jumlah } & 15 & $100 \%$ & 15 & $100 \%$ \\
\hline
\end{tabular}

Pada tabel 3 diketahui bahwa dari 15 anak, ada 5 anak (33\%) memperoleh nilai dengan kategori baik sekali sebelum diberikan senam Si Buyung, kemudian sesudah diberikan senam Si Buyung meningkat menjadi 6 anak (40\%). Ada 7 anak $(47 \%)$ memperoleh nilai dengan kategori baik sebelum diberikan senam Si Buyung, kemudian sesudah diberikan senam Si Buyung meningkat menjadi 8 anak (53\%). Ada 3 anak $(20 \%)$ memperoleh nilai dengan kategori kurang sebelum diberikan senam Si Buyung, kemudian sesudah diberikan senam Si Buyung ada 1 anak (7\%) memperoleh nilai dengan kategori cukup setelah diberikan senam Si Buyung, dan yang mendapat nilai dengan kategori kurang sudah tidak ada. Artinya ada beberapa anak meningkat nilainya dari pretest ke posttest-nya. Dengan demikian, kemampuan motorik anak sesudah diberikan senam Si Buyung lebih baik dibandingkan dengan sebelum diberikan senam Si Buyung.

Selanjutnya untuk mengetahui efektivitas senam Si Buyung dalam meningkatkan kemampuan motorik anak, dilakukan uji statistik untuk membandingkan nilai Pretest dengan Posttest. Teknik analisis data yang digunakan untuk membandingkan atau menganalisis perbedaan nilai pretest dengan posttest menggunakan Paired $t$-test (apabila data terdistribusi normal) atau Wilcoxon (apabila data terdistribusi normal). Berdasarkan uji Shapiro-Wild 
diketahui bahwa nilai signifikansi data nilai Prestest adalah 0,001 $<0,05$ berarti data nilai Pretest tidak terdistribusi normal, dan nilai signifikansi data Posttest adalah 0,021 $<0,05$ berarti data nilai Posttest juga tidak terdistribusi normal. Oleh karena itu, untuk menguji perbedaan nilai Pretest dengan Posttest menggunakan Wilcoxon. Berdasarkan hasil uji Wilcoxon diperoleh hasil sebagaimana pada tabel 4.

Tabel 4 Hasil Uji Perbedaan Nilai Pretest dengan Posttest

\begin{tabular}{llr|r|r}
\multicolumn{5}{c}{ Ranks } \\
\hline & N & Mean Rank & Sum of Ranks \\
\hline Nilai_posttest - & Negative Ranks & $0^{\text {a }}$ &, 00 &, 00 \\
\cline { 2 - 5 } Nilai_pretest & Positive Ranks & $9^{\mathrm{b}}$ & 5,00 & 45,00 \\
\cline { 2 - 5 } & Ties & $6^{\mathrm{c}}$ & & \\
\cline { 2 - 5 } & Total & & & \\
& & & & \\
\hline a. Nilai_posttest < Nilai_pretest & & & \\
b. Nilai_posttest > Nilai_pretest & & & \\
c. Nilai_posttest = Nilai_pretest &
\end{tabular}

Test Statistics ${ }^{a}$

\begin{tabular}{lr}
\hline & Nilai_posttest - Nilai_pretest \\
\hline$Z$ & $-2,692^{\mathrm{b}}$ \\
\hline Asymp. Sig. (2-tailed) &, 007 \\
\hline
\end{tabular}

a. Wilcoxon Signed Ranks Test

b. Based on negative ranks.

Pada tabel 4 diketahui bahwa mean Rank antara nilai Pretest dan Posttest adalah 5,00 dengan angka $Z$ sebesar -2,692 dengan signifikansi 0,007 < 0,05 berarti antara nilai Pretest dengan nilai Posttest terdapat perbedaan signifikan. Artinya, rata-rata kemampuan motorik kasar anak sebelum (Pretest) dan sesudah (Posttest) diberikan senam Si Buyung terdapat perbedaan signifikan (nyata). Dengan kata lain, senam Si Buyung dapat meningkatkan kemampuan motorik kasar anak.

\section{Uji Coba Lapangan Utama}

Uji coba tahap kedua ini melibatkan lebih banyak lagi anak dibandingkan dengan uji coba tahap pertama. Sebanyak 30 anak TK dilibatkan dalam uji coba lapangan utama ini. Lokasi TK yang diambil berbeda dengan lokasi TK pada uji coba terbatas, yaitu TK ABA Wonosari 2 dan TK ABA Jatipuro. Sebelum diberikan senam Si Buyung, dilakukan prestest untuk mengetahui kemampuan motorik kasar anak, dengan hasil seperti tabel 5.

Tabel 5 Kemampuan Motorik Kasar Anak Sebelum Diberikan Senam Si Buyung

\begin{tabular}{clcc}
\hline Nilai & \multicolumn{1}{c}{ Kategori } & Jumlah Anak & Persentase \\
\hline $80-100$ & Baik sekali & 1 & $3 \%$ \\
$66-79$ & Baik & 16 & $53 \%$ \\
$56-65$ & Cukup & 9 & $30 \%$ \\
$40-55$ & Kurang & 4 & $13 \%$ \\
$0-39$ & Sangat kurang & 0 & $0 \%$ \\
\hline \multicolumn{2}{c}{ Jumlah } & 30 & $100 \%$ \\
\hline
\end{tabular}

Pada tabel 5 diketahui bahwa dari 30 anak, ada 1 anak (3\%) memperoleh nilai dengan kategori baik sekali, dan ada 16 anak (53\%) memperoleh nilai dengan kategori baik. Dari temuan ini diketahui bahwa sebagian besar anak memiliki kemampuan motorik kasar dengan kategori baik sebelum diberikan senam Si Buyung. Sesudah diberikan senam Si Buyung 
selama 5 kali (hari) @ 30, kemampuan motorik kasar anak adalah sebagaimana dapat dilihat pada tabel 6 .

Tabel 6 Kemampuan Motorik Kasar Anak Sesudah Diberikan Senam Si Buyung

\begin{tabular}{clcc}
\hline Nilai & \multicolumn{1}{c}{ Kategori } & Jumlah Anak & Persentase \\
\hline $80-100$ & Baik sekali & 3 & $10 \%$ \\
$66-79$ & Baik & 18 & $60 \%$ \\
$56-65$ & Cukup & 7 & $23 \%$ \\
$40-55$ & Kurang & 2 & $7 \%$ \\
$0-39$ & Sangat kurang & 0 & $0 \%$ \\
\hline \multicolumn{2}{c}{ Jumlah } & 30 & $100 \%$ \\
\hline
\end{tabular}

Pada tabel 6 diketahui bahwa dari 30 anak, ada 3 anak (10\%) memperoleh nilai dengan kategori baik sekali, dan ada 18 anak (60\%) memperoleh nilai dengan kategori baik. Dari temuan ini diketahui bahwa sebagian besar anak memiliki kemampuan motorik kasar dengan kategori baik sesudah diberikan senam Si Buyung. Peningkatan kemampuan motorik kasar anak sebelum dan sesudah diberikan senam Si Buyung sebagaimana pada tabel 7.

Tabel 7 Perbandingan Kemampuan Motorik Kasar Anak Sebelum dan Sesudah Diberikan Si Buyung (Pretest-Posttest)

\begin{tabular}{clcccc}
\hline \multirow{2}{*}{ Nilai } & \multirow{2}{*}{ Kategori } & \multicolumn{2}{c}{ Nilai Pretest } & \multicolumn{2}{c}{ Nilai Posttest } \\
\cline { 3 - 6 } & & Jumlah & Persentase & Jumlah & Persentase \\
\hline $80-100$ & Baik sekali & 1 & $3 \%$ & 3 & $10 \%$ \\
$66-79$ & Baik & 16 & $53 \%$ & 18 & $60 \%$ \\
$56-65$ & Cukup & 9 & $30 \%$ & 7 & $23 \%$ \\
$40-55$ & Kurang & 4 & $13 \%$ & 2 & $7 \%$ \\
$0-39$ & Sangat kurang & 0 & $0 \%$ & 0 & $0 \%$ \\
\hline \multicolumn{2}{c}{ Jumlah } & 30 & $100 \%$ & 30 & $100 \%$ \\
\hline
\end{tabular}

Pada tabel 7 diketahui bahwa dari 30 anak, ada 1 anak (3\%) memperoleh nilai dengan kategori baik sekali sebelum diberikan senam Si Buyung, kemudian sesudah diberikan senam Si Buyung meningkat menjadi 3 anak (10\%). Ada 16 anak (53\%) memperoleh nilai dengan kategori baik sebelum diberikan senam Si Buyung, kemudian sesudah diberikan senam Si Buyung meningkat menjadi 18 anak (60\%). Ada 9 anak $(30 \%)$ memperoleh nilai dengan kategori cukup sebelum diberikan senam Si Buyung, kemudian sesudah diberikan senam Si Buyung ada 7 anak (23\%) memperoleh nilai dengan kategori cukup. Ada 4 anak (13\%) memperoleh nilai dengan kategori kurang sebelum diberikan senam Si Buyung, kemudian sesudah diberikan senam Si Buyung tinggal 2 anak (7\%) memperoleh nilai dengan kategori kurang. Artinya ada beberapa anak meningkat nilainya dari pretest ke posttest-nya. Dengan demikian, kemampuan motorik anak sesudah diberikan senam Si Buyung lebih baik dibandingkan dengan sebelum diberikan senam Si Buyung.

Selanjutnya untuk mengetahui efektivitas senam Si Buyung dalam meningkatkan kemampuan motorik anak, dilakukan uji statistik untuk membandingkan nilai Pretest dengan Posttest. Berdasarkan uji Kolmogorov-Smirnov diketahui bahwa nilai signifikansi data nilai Prestest adalah 0,041 < 0,05 berarti data nilai Pretest tidak terdistribusi normal, dan nilai signifikansi data Posttest adalah 0,037 < 0,05 berarti data nilai Posttest juga tidak terdistribusi normal. Oleh karena itu, untuk menguji perbedaan nilai Pretest dengan Posttest menggunakan Wilcoxon. Berdasarkan hasil uji Wilcoxon diperoleh hasil sebagaimana dapat dilihat pada tabel 8 .

Pada tabel 8 diketahui bahwa mean Rank antara nilai Pretest dan Posttest adalah 12,00 dengan angka $Z$ sebesar $-4,316$ dengan signifikansi $0,000<0,05$ berarti antara nilai Pretest dengan nilai Posttest terdapat perbedaan signifikan. Artinya, rata-rata kemampuan motorik 
kasar anak sebelum (Pretest) dan sesudah (Posttest) diberikan senam Si Buyung terdapat perbedaan signifikan (nyata). Dengan kata lain, senam Si Buyung dapat meningkatkan kemampuan motorik kasar anak.

Tabel 8 Hasil Uji Perbedaan Nilai Pretest dengan Posttest

\begin{tabular}{|c|c|c|c|c|}
\hline \multicolumn{5}{|c|}{ Ranks } \\
\hline & & $\mathrm{N}$ & Mean Rank & Sum of Ranks \\
\hline \multirow{4}{*}{$\begin{array}{l}\text { Nilai_posttest - } \\
\text { Nilai_pretest }\end{array}$} & Negative Ranks & $0^{\mathrm{a}}$ & ,00 & ,00 \\
\hline & Positive Ranks & $23^{\mathrm{b}}$ & 12,00 & 276,00 \\
\hline & Ties & $7 \mathrm{c}$ & & \\
\hline & Total & 30 & & \\
\hline
\end{tabular}

a. Nilai_posttest $<$ Nilai_pretest

b. Nilai_posttest $>$ Nilai_pretest

c. Nilai_posttest $=$ Nilai_pretest

Test Statistics ${ }^{a}$

\begin{tabular}{lr}
\hline & \multicolumn{2}{c}{$\begin{array}{c}\text { Nilai_posttest - } \\
\text { Nilai_pretest }\end{array}$} \\
\hline$Z$ & $-4,316^{\mathrm{b}}$ \\
\hline Asymp. Sig. (2-tailed) &, 000 \\
\hline
\end{tabular}

a. Wilcoxon Signed Ranks Test

b. Based on negative ranks.

\section{Uji Coba Lapangan Operasional}

Uji coba lapangan operasional melibatkan guru dan anak kelas B sebanyak 75 anak melibatkan 5 TK yaitu: TK ABA Bero 1, TK ABA Bero 2, TKIT MTA Bero, TK ABA Pundungsari, dan TK ABA Sumber Kulon di wilayah Trucuk Klaten, sehingga ujicoba ini juga berbeda dengan TK sebelumnya. Sebelum diberikan senam Si Buyung, dilakukan prestest untuk mengetahui kemampuan motorik kasar anak, dengan hasil seperti tabel 9.

\section{Tabel 9 Kemampuan Motorik Kasar Anak Sebelum Diberikan Senam Si Buyung}

\begin{tabular}{clcc}
\hline Nilai & \multicolumn{1}{c}{ Kategori } & Jumlah Anak & Persentase \\
\hline $80-100$ & Baik sekali & 6 & $8 \%$ \\
$66-79$ & Baik & 37 & $49 \%$ \\
$56-65$ & Cukup & 25 & $33 \%$ \\
$40-55$ & Kurang & 7 & $9 \%$ \\
$0-39$ & Sangat kurang & 0 & $0 \%$ \\
\hline \multicolumn{2}{c}{ Jumlah } & 75 & $100 \%$ \\
\hline
\end{tabular}

Pada tabel 9 diketahui bahwa dari 75 anak, ada 6 anak (8\%) memperoleh nilai dengan kategori baik sekali, ada 37 anak (49\%) memperoleh nilai dengan kategori baik, dan ada 25 anak $(33 \%)$ memperoleh nilai dengan kategori cukup. Dari temuan ini diketahui bahwa sebagian besar anak memiliki kemampuan motorik kasar dengan kategori baik dan cukup sebelum diberikan senam Si Buyung. Sesudah diberikan senam Si Buyung selama 5 kali (hari) @ 30, kemampuan motorik kasar anak adalah sebagaimana pada tabel 10.

Pada tabel 10 diketahui bahwa dari 75 anak, ada 10 anak (13\%) memperoleh nilai dengan kategori baik sekali, ada 45 anak (60\%) memperoleh nilai dengan kategori baik, ada 18 anak (24\%) memperoleh nilai dengan kategori cukup, ada 2 anak (3\%) memperoleh nilai dengan kategori kujrang. Dari temuan ini diketahui bahwa sebagian besar anak memiliki kemampuan motorik kasar dengan kategori baik sesudah diberikan senam Si Buyung. 
Peningkatan kemampuan motorik kasar anak sebelum dan sesudah diberikan senam Si Buyung sebagaimana pada tabel 11 .

Tabel 10 Kemampuan Motorik Kasar Anak Sesudah Diberikan Senam Si Buyung

\begin{tabular}{clcc}
\hline Nilai & \multicolumn{1}{c}{ Kategori } & Jumlah Anak & Persentase \\
\hline $80-100$ & Baik sekali & 10 & $13 \%$ \\
$66-79$ & Baik & 45 & $60 \%$ \\
$56-65$ & Cukup & 18 & $24 \%$ \\
$40-55$ & Kurang & 2 & $3 \%$ \\
$0-39$ & Sangat kurang & 0 & $0 \%$ \\
\hline \multicolumn{2}{c}{ Jumlah } & 75 & $100 \%$ \\
\hline
\end{tabular}

Tabel 11 Perbandingan Kemampuan Motorik Kasar Anak Sebelum dan Sesudah Diberikan Si Buyung (Pretest-Posttest)

\begin{tabular}{clcccc}
\hline \multirow{2}{*}{ Nilai } & \multirow{2}{*}{ Kategori } & \multicolumn{2}{c}{ Nilai Pretest } & \multicolumn{2}{c}{ Nilai Posttest } \\
\cline { 3 - 6 } & & Jumlah & Persentase & Jumlah & Persentase \\
\hline $80-100$ & Baik sekali & 6 & $8 \%$ & 10 & $13 \%$ \\
$66-79$ & Baik & 37 & $49 \%$ & 45 & $60 \%$ \\
$56-65$ & Cukup & 25 & $33 \%$ & 18 & $24 \%$ \\
$40-55$ & Kurang & 7 & $9 \%$ & 2 & $3 \%$ \\
$0-39$ & Sangat kurang & 0 & $0 \%$ & 0 & $0 \%$ \\
\hline & Jumlah & 75 & $100 \%$ & 75 & $100 \%$ \\
\hline
\end{tabular}

Pada tabel 11 diketahui bahwa dari 75 anak, ada 6 anak (8\%) memperoleh nilai dengan kategori baik sekali sebelum diberikan senam Si Buyung, kemudian sesudah diberikan senam Si Buyung meningkat menjadi 10 anak (13\%). Ada 37 anak (49\%) memperoleh nilai dengan kategori baik sebelum diberikan senam Si Buyung, kemudian sesudah diberikan senam Si Buyung meningkat menjadi 45 anak $(60 \%)$. Ada 25 anak (33\%) memperoleh nilai dengan kategori cukup sebelum diberikan senam Si Buyung, kemudian sesudah diberikan senam Si Buyung ada 18 anak (24\%) memperoleh nilai dengan kategori cukup. Ada 7 anak (9\%) memperoleh nilai dengan kategori kurang sebelum diberikan senam Si Buyung, kemudian sesudah diberikan senam Si Buyung tinggal 2 anak (3\%) memperoleh nilai dengan kategori kurang. Artinya ada beberapa anak meningkat nilainya dari pretest ke posttest-nya. Dengan demikian, kemampuan motorik anak sesudah diberikan senam Si Buyung lebih baik dibandingkan dengan sebelum diberikan senam Si Buyung.

Selanjutnya untuk mengetahui efektivitas senam Si Buyung dalam meningkatkan kemampuan motorik anak, dilakukan uji statistik untuk membandingkan nilai Pretest dengan Posttest. Berdasarkan uji Kolmogorov-Smirnov seperti terlihat pada tabel di atas diketahui bahwa nilai signifikansi data nilai Prestest adalah 0,000 $<0,05$ berarti data nilai Pretest tidak terdistribusi normal, dan nilai signifikansi data Posttest adalah $0,000<0,05$ berarti data nilai Posttest juga tidak terdistribusi normal. Oleh karena itu, untuk menguji perbedaan nilai Pretest dengan Posttest menggunakan Wilcoxon. Berdasarkan hasil uji Wilcoxon diperoleh hasil sebagaimana pada tabel 12 .

Pada tabel 12 diketahui bahwa mean Rank antara nilai Pretest dan Posttest adalah 18,50 dengan angka $Z$ sebesar -5,307 dengan signifikansi 0,000 < 0,05 berarti antara nilai Pretest dengan nilai Posttest terdapat perbedaan signifikan. Artinya, rata-rata kemampuan motorik kasar anak sebelum (Pretest) dan sesudah (Posttest) diberikan senam Si Buyung terdapat perbedaan signifikan (nyata). Dengan kata lain, senam Si Buyung dapat meningkatkan kemampuan motorik kasar anak. 
Tabel 12 Hasil Uji Perbedaan Nilai Pretest dengan Posttest

\begin{tabular}{llr|r|r}
\hline \multicolumn{5}{c}{ Ranks } \\
\hline \multicolumn{1}{c}{ N } & Mean Rank & Sum of Ranks \\
\hline Nilai_posttest - & Negative Ranks & $0^{\mathrm{a}}$ &, 00 &, 00 \\
\cline { 2 - 5 } & Nilai_pretest & $36^{\mathrm{b}}$ & 18,50 & 666,00 \\
\cline { 2 - 5 } & Positive Ranks & $39^{\mathrm{c}}$ & & \\
\cline { 2 - 5 } & Ties & 75 & & \\
\cline { 2 - 5 } & Total & &
\end{tabular}

a. Nilai_posttest $<$ Nilai_pretest

b. Nilai_posttest $>$ Nilai_pretest

c. Nilai_posttest $=$ Nilai_pretest

Test Statistics ${ }^{a}$

Nilai_posttest - Nilai_pretest

\begin{tabular}{lr}
\hline$Z$ & $-5,307 \mathrm{~b}$ \\
\hline Asymp. Sig. (2-tailed) &, 000 \\
\hline
\end{tabular}

a. Wilcoxon Signed Ranks Test

b. Based on negative ranks.

\section{Pembahasan}

Berdasarkan hasil ujicoba produk (senam Si Buyung) di sekolah TK/RA yang dilakukan melalui 3 tahap, maka diketahui bahwa hasil ujicoba pada setiap tahap menunjukkan bahwa: (1) Tahap pertama, diketahui bahwa rata-rata kemampuan motorik kasar anak setelah (Prosttest) lebih baik dibandingkan dengan sebelum (Pretest) diberikan senam Si Buyung; (2) Tahap kedua, diketahui bahwa rata-rata kemampuan motorik kasar anak setelah (Prosttest) lebih baik dibandingkan dengan sebelum (Pretest) diberikan senam Si Buyung; (3) Tahap ketiga, diketahui bahwa rata-rata kemampuan motorik kasar anak setelah (Prosttest) lebih baik dibandingkan dengan sebelum (Pretest) diberikan senam Si Buyung. Dengan demikian setelah melalui 3 tahap ujicoba, maka dapat dikatakan bahwa senam Si Buyung dapat meningkatkan kemampuan motorik kasar anak usia 4-6 (TK Kelompok B).

Hasil penelitian ini mendukung penelitian Hartini dan Abubakar yang menyimpulkan video senam ceria sangat layak dan sangat efektif sebagai media pembelajaran untuk meningkatkan ketrampilan motorik kasar siswa down syndrome (Hartina \& Abubakar, 2019). Mendukung penelitian Wijayanti dkk yang menyimpulkan keterampilan motorik kasar anak dapat ditingkatkan melalui kegiatan senam irama (Wijayanti et al., 2020). Mendukung penelitian Sukma \& Wafi yang menyimpulkan kegiatan senam irama dalam meningkatkan kemampuan motorik kasar anak (Sukma \& Wafi, 2018). Mendukung juga penelitian Alfah \& Putra yang menyimpulkan penerapan senam irama dalam meningkatkan kemampuan motorik kasar anak usia dini. Semakin banyak kegiatan yang bervariatif dan inovatif maka peluang untuk meningkatkan kemampuan motorik kasar pada anak sehingga dapat berkembang dengan optimal (Ulfah \& Putra, 2021).

Senam Si Buyung adalah salah satu cabang dari senam ritmik yang di dalamnya ada unsur gerak dan irama, yang akan ditujukan untukperkembangan sistem syaraf sensoris pada anakusia dini (Mawarti et al., 2010). Samsudin menjelaskan senam kanak-kanak (biasa disebut senam Si Buyung) ini dapat dilaksanakan dengan berbagai cara salah satunya dengan senam menurut fantasi (anak meniru gerak-gerik atau tingkah laku manusia, binatang, serta gerakan benda-benda) (Samsudin, 2008). Utami menjelaskan senam fantasi (Si Buyung) dapat dijadikan sebagai bentuk latihan untuk mengembangan motorik kasar anak usia dini. Senam fantasi yang dapat diterapkan seperti senam fantasi bentuk meniru tanpa alat, senam fantasi meniru dengan alat, dan senam fantasi dalam bentuk cerita (Baan et al., 2020).

Purwanti menjelaskan pembelajaran gerak dan lagu pada anak usia dini sangat bermanfaat untuk merangsang perkembangan anak, khususnya perkembangan fisik dan motorik anak. Melalui pembelajaran gerak dan lagu, diharapkan dapat menjadikan anak usia 
dini sebagai penerus bangsa yang lincah, berbakat, kreatif, dan bersahaja (Prahesti \& Dewi, 2020). Hasil penelitian Pradipta \& Sukoco menyimpulkan bahwa Senam Si Buyung melalui gerak dan lagu adalah aktivitas yang sangat menyenangkan bagi anak $\mathrm{TK}$, aktivitas gerak dan lagu memberi sumbangan yang besar untuk perkembangan otak anak TK (Pradipta \& Sukoco, 2013).

Abdelkarim, et al. menyatakan Physical activity (PA) sudah menjadi bagian yang sangat penting untuk proses perkembangan anak baik untuk meningkatkan kesehatan, kardiovaskuler dan sebagai sarana mereka untuk melakukan sosialisasi dengan teman sebayanya (Utoyo et al., 2021). Marinšek \& Denac menjelaskan elemen dasar gerak yang membentuk keterampilan motorik adalah kekuatan, kelincahan, keseimbangan, dan koordinasi. Keterampilan gerakan dasar merupakan bagian penting untuk perkembangan motorik seumur hidup sehingga dianggap sebagai pondasi penting untuk keterampilan olahraga dikemudian hari (Wulandari \& Asmawi, 2021).

Melo menjelaskan gerakan dasar lokomotor dapat berfungsi dengan baik bilamana saat usia dini gerakan lokomotornya sudah mengalami pematangan, karena Melalui pematangan gerakan dasar lokomotor saat anak usia dini dapat menjadi bekal yang baik untuk memulai awal perkembangan gerakan lokomotor di saat dewasa nantinya (Widiarti et al., 2021). Cheng et al. menjelaskan dengan porsi yang terukur, manfaat melatih motorik kasar anak yaitu menurunkan resiko obesitas, meningkatkan kebugaran (Pahendra et al., 2021).

Hasil pengembangan model senam Si Buyung dapat memberikan kemudahan bagi guru TK untuk memberikan latihan senam Si Buyung dalam rangka meningkatkan kemampuan motorik kasar anak, karena hasil pengembangan ini berupa buku dan video. Selain itu, model senam Si Buyung ini dapat meningkatkan motivasi belajar anak, karena gerakan senam dikembangkan dari gerakan binatang dan diiringi dengan lagu anak-anak.

\section{SIMPULAN}

Materi senam Si Buyung yang sesuai dengan karakteristik anak TK kelompok B adalah senam si Buyung dengan menirukan gerakan binatang seperti menirukan gerakan binatang kucing berlari, monyet melempar bola, ayam berjalan di atas balok, ular berlari, dan katak melompat. Pengembangan model senam Si Buyung yang telah dilakukan ujicoba di beberapa sekolah TK/RA layak digunakan oleh guru TK/RA kelompok B untuk memberikan latihan motorik kasar anak. Hasil pengembangan model senam Si Buyung secara efektif dapat meningkatkan kemampuan motorik kasar anak TK kelompok B. Hasil pengembangan model senam Si Buyung ini dapat digunakan oleh guru TK untuk meningkatkan motivasi dan hasil belajar anak dalam pembelajaran motorik kasar.

\section{UCAPAN TERIMA KASIH}

Peneliti mengucapkan terima kasih kepada kepala sekolah, guru, orang tua/wali murid, dan anak-anak yang telah berpartisipasi aktif dalam pengumpulan data.

\section{DAFTAR PUSTAKA}

Annisa, A., \& Sutapa, P. (2019). Jurnal Obsesi: Jurnal Pendidikan Anak Usia Dini The Implementation of Nature-based Learning Models to Improve Children ' s Motor Skills. 3(1), 170-182. https://doi.org/10.31004/obsesi.v3i1.140

Arikunto, S. (2015). Dasar-dasar Evaluasi Pendidikan. Bumi aksara.

Baan, A. B., Rejeki, H. S., \& Nurhayati. (2020). Perkembangan Motorik Kasar Anak Usia Dini. Jurnal Bungamputi, 6(1), 14-21.

Claudia, S., Widiastuti, A. A., Kurniawan, M., Paud, P. G., Kristen, U., \& Wacana, S. (2018). Jurnal Obsesi : Jurnal Pendidikan Anak Usia Dini Origami Game for Improving Fine Motor Skills for Children 4-5 Years Old in Gang Buaya Village in Salatiga. 2(2), 143148. https://doi.org/10.31004/obsesi.v2i2.97 
Darmiatun, S., \& Mayar, F. (2020). Jurnal Obsesi: Jurnal Pendidikan Anak Usia Dini Meningkatkan Kemampuan Motorik Halus Anak melalui Kolase dengan Menggunakan Bahan Bekas Abstrak. 4(1), 247-257. https://doi.org/10.31004/obsesi.v4i1.327

Eriani, E., \& Dimyati. (2020). Stimulasi Kreativitas Gerak Anak Melalui Senam Si Buyung. Mitra Ash-Shibyan, Jurnal Pendidikan Dan Konseling, 3(2), 88-97. https://doi.org/10.46963/mash.v3i02.159

Fitri, R., \& Imansari, M. L. (2021). Permainan Karpet Engkle: Aktivitas Motorik untuk Meningkatkan Keseimbangan Tubuh Anak Usia Dini. 5(2), 1187-1198. https://doi.org/10.31004/obsesi.v5i2.754

Hartina, W. O., \& Abubakar, S. R. (2019). Meningkatkan Keterampilan Motorik Kasar Anak Melalui Kegiatan Senam Irama. Jurnal Riset Golden Age PAUD UHO, 2(1). https://doi.org/10.36709/jrga.v2i1.8309

Hayati, S. (2020). Tangkas Fisik-Motorik dengan Permainan Tradisional. Pustaka pelajar.

Kuraedah, S., \& Anhusadar, L. O. (2020). Jurnal Obsesi : Jurnal Pendidikan Anak Usia Dini Meningkatkan Keterampilan Motorik Halus Anak melalui Mencetak dengan Pelepah Pisang Abstrak. 4(1), 211-223. https://doi.org/10.31004/obsesi.v4i1.299

Laely, K. (2020). Jurnal Obsesi : Jurnal Pendidikan Anak Usia Dini Cooking Class Berbasis Kearifan Lokal Meningkatkan Motorik Halus Anak di Daerah Miskin Abstrak. 4(2), 923-931. https://doi.org/10.31004/obsesi.v4i2.466

Marischa, S. (2017). Analisis Tingkat Pengetahuan Orang Tua tentang Stimulasi dengan Perkembangan Motorik Kasar Anak Usia 0-5 Tahun. J Agromed Unila, 2(4), 452-455.

Mawarti, S., Sukamti, E. R., \& Prasetyo, Y. (2010). Pembuatan Paket Senam Si Buyung untuk Guru-guru TK. UNY.

Meriyati, Kuswanto, C. W., Pratiwi, D. D., \& Apriyanti, E. (2021). Kegiatan Menganyam dengan Bahan Alam untuk Mengembangkan Kemampuan Motorik Halus Anak. 5(1), 729-742. https:// doi.org/10.31004/obsesi.v5i1.667

Nasution, S. T., \& Sutapa, P. (2021). Strategi Guru dalam Menstimulasi Keterampilan Motorik AUD Pada Era Pandemi Covid 19. 5(2), 1313-1324. https://doi.org/10.31004/obsesi.v5i2.849

Pahendra, Selman, H., Said, H., Sasnita, U., \& Rusli, I. T. (2021). Sirkuit Bola Keranjang: Permainan untuk Meningkatkan Kemampuan Motorik Kasar Anak Usia Dini. 5(2), 2025-2036. https://doi.org/10.31004/obsesi.v5i2.1077

Pradipta, G. D., \& Sukoco, P. (2013). Model Senam Si Buyung Untuk Pembelajaran Motorik Kasar Pada Siswa Taman Kanak-Kanak. 1(Cd), 130-141. https://doi.org/10.21831/jk.v1i2.2569

Prahesti, S. I., \& Dewi, N. K. (2020). Jurnal Obsesi : Jurnal Pendidikan Anak Usia Dini Gerak dan Lagu Neurokinestetik ( GELATIK) untuk Menumbuhkan Kreativitas Seni Anak Usia Dini Abstrak. 4(1), 162-171. https://doi.org/10.31004/obsesi.v4i1.289

Rakimahwati, Lestari, N. A., \& Hartati, S. (2018). Pengaruh Kirigami Terhadap Kemampuan Motorik Halus Anak di Taman. 2(1), 98-108. https://doi.org/10.31004/obsesi.v2i1.13

Ramdani, L. A., \& Azizah, N. (2020). Jurnal Obsesi : Jurnal Pendidikan Anak Usia Dini Permainan Outbound untuk Perkembangan Motorik Kasar Anak Usia Dini Abstrak. 4(1), 482-490. https://doi.org/10.31004/obsesi.v4i1.407

Samsudin. (2008). Pembelajaran Motorik di Taman Kanak-kanak. Litera Prenada Media Group.

Saripudin, A. (2019). Analisis Tumbuh Kembang Anak Ditinjau Dari Aspek Perkembangan Motorik Kasar Anak Usia Dini. Equalita, 1(1), 114-130. https://doi.org/10.24235/equalita.v1i1.5161

Septiana, V. T., \& Widiastuti, A. A. (2020). Jurnal Obsesi : Jurnal Pendidikan Anak Usia Dini Dukungan Orang Tua dalam Mengembangkan Motorik Kasar Anak Cerebral Palsy 
pada Anak Usia Dini Abstrak Abstract: 4(1), 172-180. https://doi.org/10.31004/obsesi.v4i1.298

Sugiyono. (2013). Metode Penelitian Pendidikan. Alfabeta.

Sujiono, Y. N., \& Sujiono, B. (2010). Bermain Kreatif: Berbasis Kecerdasan Jamak. PT. Indeks.

Sukma, T., \& Wafi, A. (2018). Peningkatkan Ketrampilan Motorik Kasar Siswa Down $\begin{array}{lllll}\text { Syndrome melalui } & \text { Senam } & \text { Ceria. } & \text { 43 }\end{array}$ https://doi.org/10.17977/um031v4i12018p043

Tanto, O. D., \& Sufyana, A. H. (2020). Jurnal Obsesi : Jurnal Pendidikan Anak Usia Dini Stimulasi Perkembangan Motorik Halus Anak Usia Dini dalam Seni Tradisional Tatah Sungging Abstrak. 4(2), 575-587. https://doi.org/10.31004/obsesi.v4i2.421

Ulfah, A. A., \& Putra, A. J. A. (2021). Analisis Penerapan Senam Irama dalam Meningkatkan Kemampuan Motorik Kasar Anak Usia Dini. 5(2), 1844-1852. https://doi.org/10.31004/obsesi.v5i2.993

Utoyo, S., Juniarti, Y., Sari, N., \& Mangge, K. (2021). Jurnal Obsesi : Jurnal Pendidikan Anak Usia Dini Pendidikan Jasmani Untuk Anak Usia Dini : Pengembangan Fundamental Movement Skill ( FMS ) pada Anak Abstrak. 5(1), 404-413. https:// doi.org/10.31004/obsesi.v5i1.605

Wandi, Z. N., \& Mayar, F. (2020). Jurnal Obsesi : Jurnal Pendidikan Anak Usia Dini Analisis Kemampuan Motorik Halus dan Kreativitas pada Anak Usia Dini melalui Kegiatan Kolase Abstrak. 4(1), 363-370. https:// doi.org/10.31004/obsesi.v4i1.347

Widiarti, Yetti, E., \& Siregar, N. (2021). Peningkatan Kemampuan Gerak Dasar Lokomotor Anak melalui Modifikasi Seni Tradisional Burok. 5(2), 1787-1798. https:// doi.org/10.31004/obsesi.v5i2.1005

Wijayanti, A., Wijayanti, A., \& Laksono, B. A. (2020). Peningkatan Kemampuan Motorik Kasar melalui Kegiatan Senam Irama. Jurnal Inovatif Ilmu Pendidikan, 2(1), 1-14. https:// doi.org/10.23960/jiip.v2i1.21785

Wulandari, M., \& Asmawi, M. (2021). Hubungan Status Gizi dan Aktivitas Bermain melalui Keterampilan Gerak Dasar Anak Taman Kanak-Kanak. 5(2), 1706-1717. https://doi.org/10.31004/obsesi.v5i2.965 